\title{
PERUBAHAN STRUKTUR AGRARIA DI HULU DAS CIDANAU KABUPATEN SERANG PROVINSI BANTEN
}

\section{(AGRARIAN CHANGES IN THE UPSTREAM OF DAS CIDANAU REGENCY OF SERANG - BANTEN)}

\author{
Hidayat \\ Fakultas Ilmu Sosial \\ Universitas Negeri Medan \\ Email: h_amsani@yahoo.com
}

\begin{abstract}
The course of peasant's history in Indonesia was colored by superlocal power domination in the form of which vary from time to time depending on the political interest and economical regime of the ruling class. The agrarian politics which oriented betting on the strong had complex impact towards rural community that caused productivity of agricultural, forestry and economic growth. But the agrarian politic capitalist that caused disparity of land of property, disparity of agrarian structure and peasant marginalization. The capitalization of agrarian resouces was due to depesanitation process systematically occurred over level system (rule of laws and policy of regulation), level organization and caused the ruling government had failed to create the objective of institutional for prosperity at large and people's welfare. The agrarian politics was failured to peasant empowerment economic aspects and conducive agrarian resources for sustainability development.
\end{abstract}

Key words: Capitalization of agrarian resources, political agrarian and depeasanitation proceses

\section{PENDAHULUAN}

Paling sedikit terdapat tiga kebutuhan manusia yang pemenuhannya berkaitan dengan tanah: (1) manusia membutuhkan tanah untuk memperoleh pendapatan guna menunjang dan kelangsungan kehidupan; (2) manusia memerlukan tanah untuk mendirikan rumah sebagai tempat tinggal; (3) manusia membutuhkan tanah untuk tempat tinggalnya yang terakhir pada saat mengakhiri hidupnya di dunia. Bagi petani seperti dikatakan More dalam (Landsberger, 1984:9), pemilikan de facto atas tanah merupakan ciri pokok yang membedakan seorang petani dengan bukan petani. Tanah tak dapat dipisahkan dan bagian dari kehidupan petani.

Wolf dalam Scott (1989) mengilustrasikan hubungan petani dengan tanah. Petani merupakan produsen pertanian dengan penguasaan efektif pada tanah, mengganggu tanah petani berarti mengusik statusnya sebagai produsen 
pertanian, karena tanah merupakan tulang punggung hidupnya. Shanin dalan Nasikun (1992) menggambarkan kaitan khusus petani dengan tanah sebagai berikut: Pertama mempunyai hubungan khusus, di mana produksi pertanian berakar pada keadaan khusus petani; kedua usaha petani merupakan satuan dasar pemilikan produksi dan konsumsi serta kehidupan sosial petani; dan ketiga kepentingan pokok pekerjaan dan menentukan kedudukan sosial, peranan dan kepribadian petani. Oleh karena itu tanah bagi petani merupakan "basis needs" tetapi struktur penguasaan dan pemilikan tanah berlangsung timpang. Di satu pihak ada kelompok orang yang memiliki dan menguasai tanah secara berlebihan, tetapi di sisi lain petani yang hidupnya tergantung dengan tanah, lapar/kekurangan tanah. Kondisi ini menunjukkan bahwa permasalahan tanah merupakan hal kompleks.

Kompleksitas masalah tanah dewasa ini dapat diidentifikasi sebagai berikut. Pertama, terjadi perubahan peranan dan kebijakan pemerintah dalam masalah pertanahan. Sebelumnya tiap persoalan tanah, pemerintah dapat menempatkan dirinya sebagai pihak yang "netral" dan tidak tersangkut dengan persoalan tanah yang muncul di masyarakat. Dewasa ini, posisi dan peran pemerintah sering menjadi pihak yang terkait, terlibat dan bagian dari masalah pertanahan. Ini terkait dengan fungsi pemerintah sebagai pengelola pembangunan yang membutuhkan tanah dan untuk mendapatkannya sering dilakukan dengan cara menggusur tanah rakyat atau membeli secara paksa dengan harga yang sangat murah.

Kedua, isu yang muncul berkaitan dengan tanah tidak lagi menyangkut "akses" seseorang atas sebidang tanah tetapi menyangkut persoalan penghargaan yang wajar terhadap hak tanah rakyat. Ketiga, masalah tanah dewasa ini bukan hanya masalah lokal atau desa dan ketidakadilan antara pemilik dengan penggarap atau penyakap, tetapi telah bergeser dan semakin kompleks. Selain masalah lokal belum terpecahkan ditambah dengan keterlibatan pihak supralokal, yakni pemilik modal dan pihak di atas supra desa yang berkepentingan terhadap penguasaan tanah rakyat di pedesaan.

Keempat, terkait dengan permasalahan pemahaman konsep fungsi sosial tanah. Konsep ini sebenarnya dimaksudkan untuk mencegah terjadinya pemilikan dan penguasaan tanah sebagai ajang spekulasi. Dalam praktik, konsep fungsi sosial tanah digunakan bukan hanya sebagai "alat untuk membebaskan tanah rakyat" tetapi juga setelah tanah dibebaskan ternyata bukan proyek pembangunan, fasilitas, pelayanan publik yang berguna bagi rakyat dan untuk kepentingan dan kemajuan ekonomi rakyat tetapi untuk kepentingan pihak lain yang tidak ada kaitan sejarah dan hubungan sosial dan teknis dengan tanah.

Keempat masalah pertanahan tersebut muncul dan terkait dengan proses pembangunan yang mendorong terintegrasinya masyarakat desa dalam negara nasional dan pasar global. Dampak lebih jauh dari proses tersebut adalah terjadinya perubahan sosial ekonomi masyarakat yang cenderung destruktif. Dalam bidang ekonomi dampak dari penetrasi negara dan kekuatan pasar 
adalah semakin terbukanya wilayah pedesaan bagi pemasaran produk industri mutakhir yang mengakibatkan berkurangnya peranan sistem ekonomi kerakyatan, turunnya daya saing dan daya tarik industri rumah tangga pedesaan. Penetrasi negara dan pasar (regional, nasional dan global) yang intensif mengakibatkan semakin sempitnya penguasaan tanah rata-rata rumah tangga petani, yakni di bawah 0,5 hektar di luar Jawa dan 0,3 hektar di Jawa.

Dalam posisi yang kurang menguntungkan itu, rumah tangga petani dan masyarakat desa pada umumnya juga dihadapkan pada posisi dilematis. Di satu sisi mereka harus menerima program dan proyek pembangunan dalam rangka perbaikan ekonomi, di sisi lain petani dan masyarakat desa menjadi ajang promosi dan kepentingan berbagai kekuatan ekonomi dan politik dari luar dan supra desa yang secara langsung dan tidak langsung menguasai sumberdaya agraria pedesaan. Penterasi kekuatan pasar yang intensif tidak jarang memaksa rumah tangga petani menukarkan hak azasi mereka dengan kesejahteraan material.

Berpangkal dari pemikiran di atas penulis tertarik untuk mengkaji (1) bentuk kelembagaan lokal tata kelola dan penguasaan tanah pada komunitas di sekitar hutan di kawasan hulu DAS Cidanau. (2) perubahan penguasaan tanah rumah tangga petani yang disebabkan kapitalisasi sumberdaya yang membonceng masuk melalui berbagai program pembangunan pedesaan. (3) Proses transfer penguasaan tanah dan dampaknya terhadap kehidupan petani. Kajian ini dilakukan didasarkan hasil penelusuran bahwa kajian tentang kapitalisasi sumberdaya agraria khsususnya yang berlangsung di kawasan DAS Cidanau setelah satu windu reformasi belum mendapat perhatian para pemerhati dan akademisi. Dari segi penelitian ini dimaksudkan untuk mengisi keterbatasan kajian tentang dinamika petani dan pedesaan pada umumnya. Secara khusus kajian ini dimaksudkan untuk menggambarkan dinamika kelembagaan lokal dan penetrasi kekuatan politik dan ekonomi supralokal pada komunitas di sekitar hutan.

\section{TINJAUAN TEORETIS}

Visi dan misi pengelolaan sumberdaya agraria (tanah, air dan hutan) menurut konstitusi ditujukan untuk sebesar-besarnya kesejahteraan rakyat. Visi dan misi konstitusi tersebut mengambarkan bahwa pendiri republik Indonesia mengarah orientasikan politik agraria populis. Dalam arti pengelolaan dan pemanfaatan sumberdaya agraria bukan hanya ditujukan untuk memenuhi kebutuhan ekonomi semata-semata, apalagi sekelompok kecil pemilik kuasa dan pemilik modal, melainkan sumberdaya agraria terdistribusi secara adil, dinikmati dan dimaksudkan untuk mewujudkan keasejahteraan masyarakat Indonesia secara keseluruhan.

Pengarusutamaan politik agraria populis yang dirumuskan oleh pendiri republik merupakan "jalan tengah" antara sosialis dan liberalis. Dalam sistem 
politik agraria sosialis, tanah dan sarana produksi dikuasi oleh negara (melalui serikat pekerja). Tenaga kerja memperoleh imbalan dari hasil kerjanya. Tanggung jawab produksi, akumulasi dan investasi berada di tangan organisasi pekerja yang dikuasai negara. Menurut sistem politik agraria sosialis, satuan usaha, sarana produksi, tenaga kerja tersebar pada mayoritas keluarga tani dan tanggungjawab atas akumulasi diatur oleh negara. Dalam politik agraria berbasis sosialis, negara memonopoli penguasaan dan pengaturan sumberdaya.

Hal ini kontras dengan politik agraria berbasis kapitalis/liberal di mana, sarana produksi utama (tanah) dikuasai oleh individu-individu non penggarap. Penggarap yang mengolah tanah adalah pekerja upahan/“bebas", diupah oleh pemilik tanah. Hubungan antara penguasaan/ pemilikan tanah dan pekerjaan terpisah. Penggarap menjual tenaga yang dibeli dengan upah oleh pemilik tanah. Kedudukan tenaga kerja dalam sistem kapitalis sebagai komoditi dan tanggungjawab produksi, akumulasi dan investasi sepenuhnya di tangan pemilik tanah.

Pendiri republik merumuskan sumberdaya agraria "dikuasai negara" untuk sebesar-besarnya kesejahteraan rakyat. Rumusan ini didasarkan pemahaman historis dan sosiologis pengelolaan sumberdaya oleh berbagai komunitas di wilayah nusantara dan suasana kebatinan penyelenggaraan pemerintahan yang akan mereka laksanakan. Pendiri republik memahami bahwa pengelolaan sumberdaya agraria oleh negara dan masyarakat, tujuan akhirnya sama, yakni terwujudnya kesejahteraan rakyat. Rumusan itu didukung oleh suasana kebatinan dan pemahaman ideal tentang kinerja birokrasi yang efisien seperti dikemukakan oleh Max Weber (1968), Negara merupakan instrumen, fasilitator, regulator dan mediator yang netral, berdiri di atas berbagai kepentingan golongan, partai dan kelompok dalam upaya mewujudkan kesejahteraan masyarakat.

Politik agraria 'jalan tengah" tersebut bersumber dan berbasis atas pemahaman sosio historis yang mendalam terhadap tradisi dan praktik pengelolaan dan pemanfaatan sumberdaya agraria yang berkembang dalam berbagai komunitas dan etnis di wilayah nusantara. Hal yang menonjol dan menjadi ciri tradisi dan praktik pengelolaan dan pemanfaatan sumberdaya agraria pada masyarakat Indonesia adalah menjunjung tinggi kohesivitas sosial, resiprositas, keseimbangan dan ketentraman hidup daripada pencapaian surplus ekonomi secara individual.

Secara ekologis dan sosiologis, politik tata kelola agraria "jalan tengah" dapat menjaga keseimbangan ekosistem dan keberlanjutan sumberdaya, kecil peluang terjadinya ketimpangan dan kemiskinan antar anggotanya, karena arah orientasi dan aktivitas tata kelolanya lebih mementingkan kebersamaan daripada kepentingan/keuntungan ekonomi individual (Dewalt, 1994). Selain itu tata kelola sumberdaya populis didukung dengan kelembagaan dan pengetahuan lokal yang "mutable immobiles" (pengetahuan yang relatif lunak dan selalu selaras dengan lingkungan lokal). Para pelakunya memiliki pengalaman yang melimpah tentang ekologi lokal dan kesadaran yang tinggi tentang keterkaitan ekologis antara manusia, fauna, flora dan tanah. Oleh karena 
itu tata kelola sumberdaya agraria berbasis populis dinilai sebagai kelembagaan yang efektif dan berkelanjutan (Brinkerhoff, Derick W, and Arthur A. Goldsmith, 1992). Karena berbasis dan berakar pada trust, menyediakan akses dan partisipasi komunitas lebih besar daripada kelembagaan formal (state property dan business property).

Meskipun tata kelola sumberdaya agraria berbasis kelembagaan kearifan lokal lebih menjanjikan keberlanjutan dan berkeadilan, sejauh ini tidak menjadi pilihan politik dan strategi pembangunan sumberdaya agraria di Indonesia. Deviasi dan kontradiksi dari semangat pendiri republik, paling tidak dapat diidentifikasi dalam dua hal. Pertama arah kebijakan dan politik agraria berorientasi kapitalis, kedua pendekatan yang digunakan dalam tata kelola sumberdaya bersifat sektoral. Amanat konstitusi yang menyatakan pengelolaan tanah dan air untuk sebesar-besarnya kesejahteraan rakyat dan cenderung menjadi "vehicle to get power" penyelenggara negara yang berkonspirasi dengan pemilik modal (pengusaha).

Arah orientasi politik sumberdaya agraria kapitalis tercermin dalam sejumlah peraturan perundangan dan praktik penyelengaraan pemerintahan selama rezim Orde Baru dan satu dekade era reformasi atau era otonomi daerah. Kecuali TAP MPR No.IX/2001 tentang Pembahruan Agraria dan Pengelolaan Sumberdaya Alam, hampir semua peraturan perundang-undangan yang dihasilkan dari reformasi tidak berbeda signifikan dengan peruduk perundangundangan yang dikeluarkan pada masa rezim Orde Baru, yakni abai terhadap kesejahteraan rakyat, berpihak dan melayani kepentingan pasar nasional dan global. Hal ini tercermin misalnya UU No. 7/2004 Tentang Sumber Daya Air; Perpu No.1/ 2004 tentang Perubahan Undang-Undang No. 41/1999 tentang Kehutanan; UU No.25/2007 tentang Penanaman Modal, UU No. 27/2007 tentang Pengelolaan Wilayah Pesisir dan Pulau-Pulau Kecil dan UU No. 4/2009 tentang Pertambangan dan Mineral. Berbagai regulasi kebijakan pengelolaan dan pemanfataan sumberdaya cenderung memfasilitasi dan membuka akses kepada pemilik modal untuk menguasai sumberdaya melalui "mekanisme pasar": supply and demand.

Dalam kondisi penyelenggaraan negara bersifat transaksional, menguatnya ego sektoral dan ego kedaerahan, berpotensi menimbulkan ketimpangan struktur agararia, menyuburkan pelaku usaha oportunis dan perilaku koruptif yang berujung pada degradasi sumberdaya. Pemilik modal, pengusaha yang memiliki jaringan pertemanan dan akses terhadap kekuasaan, memonopoli sumberdaya agraria (hutan dan pertambangan) secara berlebihan, sementara sebagian besar masyarakat yang hidupnya tergantung pada sumberdaya agraria, berkeluh keringat dan mencucurkan darah memperebutkan setapak tanah untuk mempertahankan kelangsungan hidupnya.

Transformasi hak sumberdaya dari indigenous property dan common property ke state property dan private/business property yang prosesnya berjalan seiring dengan proses transformasi politik dan dianggap sebagai syarat menuju masa depan negara modern. Dalam kenyataan empirik menyebabkan relasi dan 
pergulatan penguasaan sumberdaya agraria berlangsung timpang, menempatkan tata kelola sumberdaya berbasis kelembagaan dan kearifan lokal menjadi obyek kepentingan sosial dan ekonomi supra lokal dan global (Escobar, 1999). Transformasi penguasaan tanah juga mendorong meluasnya konflik agraria tenurial dan mengakibatkan dekonstruksi sosial, alienasi masyarakat (Ellen, 2002) dan menjadikan petani sebagai buruh upahan atau kuli (Bremen, 1997).

\section{METODOLOGI PENELITIAN}

Penelitian ini dimaksudkan untuk memperoleh pemahaman mengenai penguasaan tanah dan proses transfer penguasaan tanah dan dampaknya terhadap kehidupan petani hutan yang bermukim di hulu DAS Cidanau. Pendekatan dan metodologi yang digunakan adalah metodologi kritis (Lubis, 2004; Agger, 2003). Penggunaan metodologi kritis didasarkan pertimbangan posisi tineliti yang termarginalkan dan rendahnya perhatian agensi terhadap kelembagaan lokal dan praktik tata kelola sumberdaya agraria komunitas, meskipun kondusif untuk konservasi sumberdaya kawasan hulu DAS.

Dengan menggunakan metodologi kritis dapat membongkar dimensi struktur pengetahuan dan kekuasaan yang mengalienasi komunitas dan mendorong kesadaran kolektif (collective conscious-ness) tineliti, melakukan perubahan dan perbaikan terhadap posisi sosial dan ekonominya yang termarginalkan. Sehingga penelitian ini dapat dikategorikan sebagai kritik sosial, atau dalam istilah Cavallaro (2004) sebagai riset transformatif. Peneliti dan tineliti terjalin interaksi dan dialogis, realitas dan temuan diletakkan dalam kerangka pemikiran dunia peneliti dan peneliti (Ritzer \& Douglas, 2004). Pendekatan etik dan emik tidak dipertentangkan tetapi disinergikan (Kaplan dan Manners, 1999).

Penelitian dilakukan di tiga desa di kawasan DAS Cidanau, yakni Desa Citasuk dan Desa Cibojong Kecamatan Padarincang dan Desa Citanam Kecamatan Ciomas Kabupaten Serang. Pemilihan lokasi atas pertimbangan (1) Desa Citanam merupakan salah satu desa di kawasan hulu DAS Cidanau secara sejarah sosiologis memiliki keunikan, adanya kelembagaan buyut, pipeling, liliuran, tanah kajaroan dan tanah kaguronan. (2) Di DAS Cidanau terdapat Cagar Alam Rawa Danau sebagai kawasan endemik situs konservasi rawa pegunungan satu-satunya yang tersisa di P. Jawa dan adanya jejaring kelembagaan hubungan hulu hilir dalam bentuk mekanisme pembayaran jasa lingkungan yang kondusif untuk tata kelola DAS terpadu.

Jumlah informan yang dipilih sebanyak 56 orang secara purposive snowball sampling berdasarkan kriteria (1) mereka yang menjadi bagian dari peristiwa dan mengetahui masalah yang diteliti. (2) Representasi, informan yang terpilih berasal dari beragam latar belakang sosial: petani, pejabat pemerintahan, pamong desa, tokoh masyarakat, pengurus/anggota LSM dan kelompok tani. 
Kegiatan penelitian berlangsung Oktober 2008 sampai dengan Maret 2009 secara periodik dengan maksud untuk mengambil jarak dengan tineliti.

Pengumpulan data dilakukan melalui pengamatan partisipasi, wawancara mendalam, Focus Group Discussion (FGD), dan studi dokumentasi. Wawancara mendalam dilakukan untuk menggali informasi, keterangan dan penjelasan dari tineliti/aktor yang terlibat dalam kelembagaan komunitas, implementasi kebijakan yang berdampak pada penggusuran petani. Wawancara mendalam dengan tineliti dilakukan secara lepas dengan terlebih dahulu menyiapkan pokok-pokok pertanyaan yang diajukan. Narasumber/informan kunci wawancara mendalam berasal dari berbagai strata, kelompok dan organisasi baik formal dan informal di tingkat desa, instansi teknis (pertanian, kehutanan, UPT DAS, FKDC) dan LSM.

Informasi, keterangan dan penjelasan yang digali melalui wawancara mendalam dijadikan bahan diskusi kelompok berfokus (Focus Group Discussion). Pesertanya adalah informan kunci (tokoh masyarakat, pengurus dan anggota kelompok tani, aparat desa, pejabat instansi teknis dan aktivis LSM) yang dikelompokkan sesuai dengan stratanya agar terhindar dari rasa sungkan.

Observasi partisipasi dilakukan untuk mendeteksi pola perilaku sosial dalam merespon tekanan struktural dan kelembagaan. Observasi partisipasi ditujukan untuk mengamati secara langsung pengalaman, tindakan sosial/kolektif dan individual, hubungan teknis agraria dan jaringan kelembagaan komunitas.

Data yang terkumpul diolah dengan menggunakan pendekatan analisis kualitatif. Analisis data kualitatif merupakan penelusuran terhadap pernyataanpernyataan tentang hubungan antara berbagai kategori data untuk mengkonstruksi suatu fenomena sosial atau proses mengatur urutan data dan mengorganisasikan ke dalam suatu pola kategori dan satuan uraian dasar. Pengkategorian data disesuaikan dengan pertanyaan penelitian untuk memudahkan seleksi, deskrispsi, interpretasi dan analitis dan konstruksi.

Tahapan analisis data dalam penelitian ini merujuk pada pendapat Mathew dan Michael, (1992) meliputi tiga tahapan: (1) membandingkan kejadian/fenomena yang cocok dengan kategorinya; (2) mengintegrasikan kategori dengan ciri-cirinya; (3) merumuskan kosep dan "teori" yang relevan. Pada tahap kategorisasi kejadian atau fenomena sosial dimulai dengan mengelompokkan berdasarkan nama, fungsi atau alasan tertentu. Dalam upaya memperoleh kebenaran ilmiah, data/ informasi diuji silang melalui teknik triangulasi metode, triangulasi sumber dan triangulasi teori (Lubis, 2003, 2004). Data dan informasi hasil wawancara dengan informan kunci dibandingkan dengan hasil diskusi berfokus, selanjutnya dibanding ulang dengan data hasil pengamatan berperan serta yang dilakukan di kancah dan ajang sosial dalam masyarakat. Abstraksi dan ekplanasi data dan informasi dirumuskan setelah kesepemahaman inter-subyektif peneliti dan tineliti. 


\section{HASIL DAN PEMBAHASAN}

\section{Kondisi Geografis Wilayah}

Secara geografis desa/lokasi penelitian dijelaskan sebagai berikut. Desa Citasuk sebagian wilayahnya daratan rendah dan tanah tadah hujan, sebagian besar aktivitas ekonomi penduduk untuk memenuhi kebutuhan pokoknya menanam padi, palawija dan berdagang. Hal Ini berbeda dengan kondisi geografis Desa Cibojong terbagi atas dua bagian, bagian bawah geografinya didominasi daratan rendah, lahan sawah dan bagian atas terdiri dari lereng perbukitan yang digunakan penduduk untuk pertanian lahan kering. Kondisi geografi dan topografi Desa Citaman memiliki kategori desa hutan dan sebagian besar aktivitas penduduknya adalah berladang, menanam tanaman perkebunan dan agroforestry. Lokasi desa Citaman terletak di bagian Selatan kaki Gunung Pangarang pada ketinggian sekitar 350 meter dari permukaan laut, sedangkan Wilayah Desa Citasuk dan Desa Cibojong sekitar 300-325 meter dari permukaan laut. Wilayah Desa penelitian dengan desa-desa sekitarnya dihubungkan oleh area perkebunan rakyat, perkampungan, sungai, dan batas alam lainnya.

Bagi penduduk, kondisi topografi dan geografi bukan hanya sebagai sarana mencari nafkah tetapi juga tempat tinggal sekaligus sarana membangun relasi sosial dan kultural dengan lingkungannya. Ikatan sosial kultural penduduk dengan lingkungannya terlihat dari kelembagaan lokal tata kelola sumberdaya agraria yang hidup pada desa tersebut. Area perkebunan rakyat penduduk Desa Citaman berada di sekitar kampung terpencar mengikuti pola penyebaran penduduk. Perkampungan wilayah Desa Citaman dikelilingi oleh kebun penduduk. Ini berbeda dengan perkampungan desa Citasuk, dikelilingi batas alam (sungai, rawa dan sawah) dan batas buatan (jalan/gang). Landscape (bentang darat) perkampungan Desa Citasuk membentang dari Barat ke Timur, dengan pusat pemerintahan berada di tengahnya. Bila diletakkan dalam pembagian wilayah menurut Geertz (1983) Desa Citaman dan Cibojong merupakan desa yang berada di wilayah Indonesia "dalam", tetapi memiliki karakteristik topografi wilayah Indonesia luar. Sedangkan kondisi geografi Desa Citasuk merupakan perpaduan Indonesia "dalam" dan wilayah Indonesia "luar".

Landscape perkampungan masing-masing desa, tampaknya berimplikasi pada intensitas interaksi sosial dan pertukaran informasi masyarakatnya inward looking atau outward looking. Pembagian wilayah desa atas dan bawah, ternyata bukan hanya secara fisik tetapi berkaitan dengan perbedaan akses dan posisi politik. Pertukaran informasi antar penduduk Desa Citaman dan Cibojong cenderung inward looking; kohesivitas, kerukunan dan kebersamaannya lebih kuat dibandingkan yang berlangsung di Desa Citasuk yang bersifat outward looking.

Sebaran pemukiman penduduk yang terpilah atas dan bawah pada Desa Citaman dan Cibojong ternyata ada kaitannya dengan hubungan sosial super 
ordinate-sub ordinate. Di mana pemegang kekuasaan (ruling class) dan pusat pemerintahannya pada kedua desa dikuasai oleh penduduk yang bermukim di bagian bawah desa. Kondisi ini tidak terjadi di desa Citasuk, pemukiman penduduknya tidak terbentuk atas dan bawah, melainkan menyebar pada sejumlah kampung. Struktur sosial dan politiknya didasarkan tingkat penguasaan dan pemilikan aset ekonomi (tanah, bentuk rumah, tingkat penghasilan, kendaraan bermotor dan peralatan rumah tangga dan jenis pekerjaan).

Struktur fisik wilayah desa dengan variasinya juga berpengaruh terhadap aktivitas pertanian, demografi dan ekonomi penduduk. Pengaruh kondisi geografi desa terhadap demografi, antara lain terlihat dari perbedaan kepadatan, sebaran dan struktur penduduk desa. Pada desa di mana struktur fisiknya sebagian besar berlereng dan berbukit, kepadatan penduduknya lebih rendah dibandingkan desa yang struktur fisiknya sebagian besar dari dataran. Struktur penduduk pada ketiga desa didominasi oleh kelompok umur 19-55 tahun, masing-masing mencapai $29,55 \% ; 29,03 \% ; 24,90 \%$. Kelompok umur selanjutnya yang dominan adalah penduduk berumur 16 - 18 tahun, desa Citaman: 21,99\%, desa Citasuk: 22,69\%, dan desa Cibojong sebesar 23,61\%. Pada masyarakat pedesaan penduduk dalam kelompok umur 16-18 tahun termasuk kategori usia produktif, masuk dunia kerja dan banyak telah melangsungkan pernikahan.

Bila kelompok umur 16 - 18 tahun dihitung sebagai kelompok umur produktif, maka kelompok umur produktif di desa Citaman sebesar 51,54\%, desa Citasuk mencapai 51,72\% dan desa Cibojong 48.51\%. Jika kelompok umur produktif dihitung dari 16-55 tahun dibandingkan dengan kelompok umur belum produktif (0-15 tahun) dan kelompok umur kurang produktif (>55 tahun), maka perbandingan komposisinya di tiga desa penelitian adalah: Desa Citaman 54\%, 40,96\%, 7,5\%; Desa Citasuk 51,72\%, 34,06\%, 14,22\%, dan Desa Cibojong 48.51\%, 36,20\%, dan 15,29\%. Data itu menunjukkan beban kelompok usia produktif paling besar terdapat di desa Cibojong, mereka harus menanggung kelompok usia tidak produktif dan kurang produktif sebesar $51,49 \%$. Tingginya beban penduduk usia produktif di desa Cibojong disebabkan tingginya persentase kelompok usia kurang produktif. Beban penduduk kelompok usia produktif yang relatif kecil terdapat di desa Citaman, karena kelompok usia produktif secara nyata masuk dan terlibat dalam berbagai mata pencaharian dan pekerjaan baik di dalam desa maupun di luar desa.

\section{Struktur Mata Pencaharian Penduduk}

Struktur mata pencaharian penduduk pedesaan pada umumnya dipengaruhi oleh ketersediaan daya dukung sumberdaya dan tata letaknya. Sumber mata pencaharian ketiga desa berada di sekitar desa dan di luar wilayah pemukiman. Merujuk pada tipologi yang dikemukakan Smith dan Zopf, (1970) tipe pemukiman penduduk ketiga desa dikategorikan sebagai the farm village tipe (FVT), yakni pola pemukiman di mana penduduk/petani tinggal bersama-sama dan berdekatan dengan lahan pertanian atau sekitar pemukiman. 
Sumber mata pencaharian penduduk di lokasi penelitian dibedakan atas sektor pertanian dan bukan pertanian. Sektor pertanian menjadi sumber mata pencaharian/sumber nafkah utama warga di tiga desa, baik sebagai petani pemilik, penggarap bagi hasil, pemegang hak gadai atau buruh tani. Persentase pekerjaan sebagai petani di desa Citaman, petani pemilik 49,03\% dan petani penggarap 21,75\%, Desa Citasuk petani pemilik 37,12\% dan petani penggarap 25,58\%; Desa Cibojong petani pemilik 39,87\%, dan petani penggarap 29,16\%. Bila petani pemilik dan penggarap digabung maka pekerjaan sebagai petani di Desa Citaman mencapai 70,78\%; Desa Citasuk sebesar 62,70\%; dan Desa Cibojong $69,03 \%$. Di Desa Citasuk persentase petani relatif kecil disebabkan proses pembangunan ekonominya lebih intensif dan letaknya yang strategis (pinggir jalan) dan semakin terbukanya jenis pekerjaan di luar sektor pertanian (pedagang, buruh industri atau pegawai). Kondisi ini ditambah nilai upah buruh tani yang lebih rendah dari UMR daerah, sehingga sektor non pertanian di kota lebih memberikan harapan dari pada sebagai petani. Salah satu bidang pekerjaan di luar pertanian yang menjadi pilihan penduduk desa, adalah buruh bangunan dan buruh industri. Pekerjaan buruh bangunan, biasanya dilakukan jika pekerjaan di huma, kebun dan sawah masa rengse (sedang sepi). Keterlibatan warga sebagai buruh bangunan dan buruh industri karena adanya jaringan sosial (kekerabatan, ketetanggaan dan pertemanan). Jaringan sosial/ pekerjaan buruh bangunan biasanya diawali dari salah satu warga mereka sebagai mandor atau tukang. Mereka yang terlibat dalam pekerjaan buruh bangunan, biasanya bekerja secara kelompok melalui mobilitas sirkulasi setahap dan tidak menetap. Hal serupa pada penduduk yang menjadi buruh industri, sebagian besar didapatkan melalui jaringan sosial dan individual dengan pola mobilitas sirkulasi linier dan dilakukan secara bertahap kemudian menetap.

Jenis pekerjaan lain penduduk adalah kerajinan/industri rumah tangga. Salah satu kerajinan yang memiliki nilai sosial historis dan ekonomi di wilayah Ciomas dan Padarincang adalah kerajinan golok. Kerajinan golok menjadi pranata ekonomi tradisional masyarakat Ciomas dan sekitarnya, bukan hanya menyerap lapangan kerja dan sumber nafkah sebagian warga, tetapi juga merupakan aktivitas ekonomi yang menopang keberlangsungan dan eksistensi lapisan sosial jawara. Ketika posisi jawara semakin terdesak karena munculnya elit politik formal dan meluasnya pembangunan pedesaan, kerajinan golok semakin tidak popular. Keruntuhan kerajinan golok Ciomas karena tidak mampu bersaing dengan produk sejenis berasal dari luar daerah dan impor yang membanjiri wilayah Ciomas dan Padarincang. Upaya mengembalikan populeritas kerajinan golok Ciomas dilakukan Pemda setempat dengan membuat golok "raksasa", berukuran panjang $7 \mathrm{~m}$, lebar $40 \mathrm{~cm}$ dan berat 2000 $\mathrm{kg}$ pada tahun 2005. Golok yang dibuat oleh pengrajian golok Ciomas tercatat oleh Musium Record Indonesia (MURI) sebagai golok terbesar dan terpanjang di Indonesia. Tetapi pencatatan golok Ciomas dalam MURI tidak mampu membangkitkan kejayaan industri golok di wilayah itu. 


\section{Kelembagaan Agraria}

Kelembagaan agraria yang terdapat di wilayah kesultanan Banten yang berkaitan dengan penguasaan tanah adalah sawah negara, sawah ganjaran/pusaka laden atau pecaton, tanah kawargaan, tanah kanayakan, tanah pangawulaa dan tanah yasa. Sawah nagara atau tanah kerajaan merupakan bentuk penguasan tanah yang pertama di wilayah kesultanan Banten dan diperkenalkan oleh keluarga kerajaan Demak dan Cirebon. Sawah negara pada umumnya dianggap sebagai tanah kesultanan. Karena itu sawah negara merujuk kepada semua sawah yang telah dibuka atas perintah sultan atau anggota keluarganya yang telah dihadiahi tanah itu sehingga sawah itu menjadi miliknya. Petani yang menggarap sawah nagara dapat dibedakan atas dua kategori: (1) petani mardika, yakni orang-orang yang telah diberi status sebagai orang merdeka oleh karena mereka telah menyatakan tunduk kepada Sultan dan telah memeluk Islam. (2) kaum abdi yakni petani yang menggarap sawah nagara, karena ditaklukan dengan kekerasan dan dijadikan sebagai budak. Petani yang menggarap sawah nagara diwajibkan membayar upeti kepada sultan sebesar sepersepuluh dari hasilnya.

Sawah ganjaran/pusaka laden atau pecaton adalah sawah atau tanah yang dianugrahkan oleh sultan. Sebutannya bervariasi sesuai dengan orang yang menerima hadiah. Disebut sawah kewargaan jika tanah/sawah itu diberikan kepada anak-anak sultan dari isteri-isterinya yang sah. Disebut sawah kanayakan jika tanah/sawah diberikan kepada anak-anak sultan dari selir-selirnya atau kepada orang-orang kesayangan sultan. Disebut sawah pangawulaan, jika sawah atau tanah itu dihadiahkan kepada pejabat-pejabat yang menggunakan hasilnya untuk membiayai hidup mereka selama masa jabatannya.

Kedua golongan pertama yang dianugrahi tanah itu tidak hanya berhak atas bagian hasil panen yang tadinya diserahkan kepada sultan, akan tetapi juga berhak untuk menggunakan tenaga kerja rakyat untuk membuka tanah baru atau untuk melakukan pelbagai macam kerja bakti baginya. Pemegang tanah kawargaan dan tanah kanayakan berhak atas bagi hasil panen dan tenaga kerja (cacah) untuk membuka tanah baru atau untuk melakukan pelbagai macam kerja bakti. Sawah ganjaran/pusaka laden atau pecaton merupakan hak penguasaan sultan dianggap telah diberikan untuk selamanya dan biasanya tanah itu diwariskan secara turun temurun hanya saja tidak dapat dipindah-tangankan kepada pihak lain tanpa persetujuan sultan.

Mengingat tanah ganjaran/pusaka laden terbatas, banyak pemegang haknya kemudian membuka tanah baru dengan menggunakan hak atas kerja bakti yang melekat pada tanah-tanah pusaka itu. Dengan membuka tanah baru mereka tidak hanya menambah pendapatan tetapi mendapatkan tanah atas dasar hak penuh. Tanah yang dibuka dengan demikian disebut tanah yasa. Petani yang menggarap tanah yasa harus membayar upeti kepada sultan atau orang yang dihadiahi tanah itu sebagai tanda patuh yang dinamakan pakukusut.

Dari beberapa bentuk penguasaan tanah tersebut yang terdapat di lokasi penelitian adalah kelembagaan penguasaan tanah kajaroan dan tanah kaguronan dan sekaligus merupakan keunikan penguasaan tanah di lokasi penelitian. Tanah kaguronan merujuk pada peruntukan dan pemanfaatan tanah untuk 
tujuan pengembangan pendidikan. Status tanah kaguronan merupakan tanah wakaf (tanah yang diberikan oleh warga untuk kepentingan syi'ar Islam) terutama kemajuan pendidikan Islam. Tanah kajaroan adalah tanah jabatan yang dimiliki aparat desa khususnya sekretaris desa berupa kebun/lahan kering sedangkan tanah jabatan kepala berupa sawah disebut sawah pangiwaan.

Berkaitan dengan sejarah status tanah kaguronan (di desa Citaman) terdapat dua sumber. Sumber pertama menyatakan bahwa tanah kaguronan berasal dari wakaf warga untuk kemajuan pendidikan Islam. Pendapat ini didukung oleh fakta sampai sekarang di sekitar tanah kaguronan masih terdapat Pondok Pesantren Subulus Salam yang diasuh oleh Kyai Mufti. Sumber kedua menyatakan bahwa tanah keguronan berasal dan merupakan hadiah dari Kesultanan Banten pada masa Sultan Agung Tirtayasa atas jasa masyarakat Ciomas dalam pengembangan pendidikan Islam. Tanah tersebut diberikan oleh Sultan Banten kepada para guru yang menyiarkan agama Islam di wilayah Ciomas. Tanah keguronan adalah pertanda kepedulian dan terima kasih Sultan kepada para guru yang telah mengembangkan pendidikan Islam. Pendapat kedua argumentasinya tidak didukung oleh fakta keterkaitan antara masyarakat Citaman dengan kesultanan Banten. Dewasa ini sebagian tanah kaguronan menjadi tempat kantor kelurahan dan lapangan sepak bola "milik" Pemerintah Kecamatan Ciomas.

Sebelum terbentuknya pemerintahan desa, di Desa Citaman terdapat kelembagaan kajaroan, pimpinannya disebut jaro yang berperan sebagai pengelola pemerintahan desa dan berhak atas tanah kajaroan (istilah lokal untuk tanah jabatan). Kajaroan merupakan kelembagaan lokal dan berperan sebagai pemerintahan "adat". Bagai kesultanan Banten lembaga kajaroan merupakan sarana mobilisasi ekonomi, tenaga kerja dan perpanjangan tangan Sultan di wilayah pedesaan dan sekaligus menjadi tulang punggung stabilitas politik. Kajaroan bertugas menentukan tata cara dan haluan pemerintahan, menyelenggarakan musyawarah bersama kokolot untuk menentukan pelaksanaan kegiatan pertanian.

Dalam kehidupan sosial, jaro berperan sebagai "pengetua adat", perekat dan pengikat tata hubungan antar anggota masyarakat dan kesultanan. Dalam tata kelola sumberdaya agraria, kajaroan memiliki kewenangan administratif dan bertanggungjawab menyelesaikan persoalan tanah. Kajaroan bertindak sebagai penghubung antara kajaroan dengan "abdi dalem" yang diangkat dan diberi tugas oleh Sultan untuk memungut upeti dan pajak dari petani serta cukai perdagangan dari pedagang) dan sebagai imbalannya, Sultan memberikan tanah pangawulaan.

\section{Sistem Pewarisan dan Fragmentasi Penguasaan Tanah}

Dampak dari komoditifikasi dan komersialisasi sumberdaya agraria, di lokasi penelitian adalah meluasnya alih tangan penguasaan dan pemilikan tanah melalui jual beli dan meningkatnya tanah in-absentia. Proses alih tangan lainnya yang menonjol adalah melalui warisan, gadai dan hibah. Proses alih tangan pemilikan tanah melalui warisan dan gadai tidak menyebabkan jatuhnya 
penguasaan tanah kepada "orang kota", karena penerima waris tanah dan penerima gadai, umumnya merupakan penduduk lokal. Lain halnya dengan alih tangan melalui jual beli, mengakibatkan jatuhnya penguasaan dan pemilikan tanah kepada bukan petani (orang kota, petani berdasi serta kelompok sosial lainnya yang diuntungkan oleh proses pembangunan).

Proses alih tangan penguasaan dan pemilikan melalui warisan yang berlangsung di lokasi penelitian, didasarkan hukum Islam dan adat Sunda. Kedua sistem pewarisan, terdapat perbedaan penting terutama berkaitan dengan jumlah hak waris yang diperoleh laki-laki lebih besar daripada perempuan. Pelaksanan sistem warisan mengatur di mana "Bagian hak waris anak laki-laki lebih besar dari pada hak waris yang diterima anak perempuan. Hak waris anak laki-laki lebih besar, karena anak laki-laki harus nanggung (penanggung jawab rumah tangga), sedangkan perempuan "nyalindung" (ikut) pada suami. Pembagian warisan dilakukan secara proporsional dan adil, yang memiliki tanggung jawab lebih besar mendapat bagian lebih besar dan sebaliknya yang tanggung jawabnya kecil mendapat bagian kecil.

Ini berbeda dengan sistem pewarisan menurut adat Sunda, laki-laki dan perempuan memperoleh bagian yang "setara". Sistem pembagian waris menurut adat, cenderung memberikan keistimewaan kepada anak sulung dan atau anak bungsu. Sistem pewarisan tanah menurut adat Sunda: Anak sulung dan atau anak bungsu dalam pembagian warisan tanah sering diprioritaskan, seperti mendapatkan tanah kebun yang lebih subur. Sementara anak perempuan sering diutamakan untuk menempati rumah yang merupakan hak milik bapaknya, terutama jika anak laki-lakinya telah memiliki rumah.

Sistem pembagian warisan baik menurut Islam maupun adat biasanya dilakukan secara lisan dan enggan mendaftarkan tanah warisnya pada pejabat berwenang. Hal ini disebabkan pemilik waris terjalin ikatan keluarga, sehingga kecil kemungkinannya terjadi konflik tanah warisan. Keengganan pemilik waris mendaftarkan tanah waris, karena enggan mengeluarkan biaya administrasi yang berkisar 2,5 - 5 persen dari nilai jual objek pajak (NJOP) tanah.

Proses alih pemilikan tanah melalui warisan merupakan salah faktor penyebab fragmentasi pemilikan tanah di hulu DAS Cidanau. Ini ditunjukkan dari pemilikan tanah pada sejumlah keluarga yang sebelumnya dikenal sebagai tuan tanah, seperti dialami keluarga BHR yang sebelumnya memiliki tanah sekitar 5 hektar, setelah diwariskan kepada anak-anaknya masing-masing mendapat hak waris seluas 1,1 hektar. Sekarang Cucu BHR hanya menguasai tanah 0,5 hektar, bahkan di antara keponakan (cucu BHR) harus puas menjadi penggarap tanah keluarga dan jadi bujang (penggarap) tanah dari orang kota. Pada kasus keluarga BHR dari empat anaknya, hanya anak sulung yang bertambah tanahnya meski tidak signifikan. Fragmentasi pemilikan tanah keluarga BHR, disebabkan alih tangan melalui warisan, gadai dan penjualan oleh generasi kedua dan ketiga. Akibat gadai dan penjualan tanah, tiga dari sembilan cucu BHR hanya memiliki tanah pekarangan dan tanah tempat tinggalnya. 
Fragmentasi penguasaan tanah oleh rumah tangga petani berkontribusi menurunnya nilai tukar produk pertanian sehingga kegiatan usaha tani tidak lagi dapat memenuhi skala ekonomi. Kondisi ini ditambah dengan kebijakan moneter dan fiskal yang memangkas dan menghapus subsidi untuk sektor pertanian dan golongan ekonomi lemah, karena tenakanan jaringan ekonomi keuangan nasional dan global.

\section{Penggusuran Petani (Depeasanitation Processes)}

Selain fragmentasi penguasaan tanah, fenomena yang menonjol di lokasi penelitian dalam lima tahun terakhir adalah meningkatnya transasksi gadai dan penjualan tanah. Bahkan dalam keadaan terdesak, sejumlah petani bukan hanya menggadaikan tanah kebun yang menjadi sumber kehidupannya, tetapi juga tidak jarang aset rumah tangga lainnya termasuk pepohonan yang bernilai ekonomi. Penggadaian pepohonan biasanya dilakukan jika bantuan atau pertolongan yang dibutuhkan tidak diperoleh. Cara ini dilakukan terutama oleh petani yang memiliki lahan kebun $<0,5$ hektar, sedangkan pemilik lahan luas $(>3$ hektar) untuk pengembangan dan diversifikasi usaha atau akumulasi modal. Faktor yang mendorong meningkatnya proses transaksi gadai dan jual beli tanah di lokasi penelitian disajikan pada Tabel 1.

Tabel 1. Jenis Kebutuhan Petani Yang Mendorong Transfer Tanah

\begin{tabular}{|c|c|c|c|c|c|c|}
\hline \multirow[t]{2}{*}{ No } & \multirow{2}{*}{$\begin{array}{l}\text { Jenis Kebutuhan Petani } \\
\text { A. Kebutuhan Konsumtif }\end{array}$} & \multicolumn{4}{|c|}{ Kelompok Tani Hutan } & \multirow{2}{*}{$\begin{array}{l}\text { Jumlah } \\
\text { Kasus }\end{array}$} \\
\hline & & KM1 & KM 2 & KM 3 & KM 4 & \\
\hline 1 & a. Rehab/bangunan rumah & 2 & 3 & 1 & 2 & 8 \\
\hline 2 & b. Pesta perkawinan & 2 & 3 & 2 & 2 & 9 \\
\hline 3 & c. Beli alat elektronik & 2 & 1 & 2 & 1 & 6 \\
\hline 4 & d. Kebutuhan mendesak & - & - & 1 & 2 & 3 \\
\hline 5 & $\begin{array}{l}\text { e. Membeli motor } \\
\text { B. Pengembangan Usaha }\end{array}$ & 2 & 1 & - & - & 3 \\
\hline 6 & a. Modal usaha & 2 & 1 & 2 & - & 5 \\
\hline 7 & b. Gadai/beli kebun & 1 & - & 1 & 1 & 3 \\
\hline 8 & C. Biaya Pendidikan & - & 1 & 1 & 1 & 3 \\
\hline 9 & D. Ibadah Haji & 2 & 1 & - & - & 3 \\
\hline & Jumlah Kasus & 13 & 11 & 10 & 9 & 43 \\
\hline
\end{tabular}

Sumber: Diolah dari informan kunci dan buku leter C

Dari Tabel 1 diketahui bahwa ada sembilan penyebab rumah tangga petani menggadaikan tanahnya. Dari sembilan penyebab transfer penguasaan tanah tersebut kebutuhan untuk memenuhi perkawinan, merehab membangun rumah dan modal usaha merupakan faktor dominan. Penyebab lainnya yang mendorong transfer penguasaan dan pemilikan tanah di lokasi penelitian adalah untuk memenuhi kebutuhan yang dikategorikan mendesak, keperluan 
pendidikan (menyekolahkan anak), tambahan biaya untuk menggadai dan membeli tanah dan tambahan biaya untuk menunaikan ibadah haji.

Kelompok sosial yang bertindak sebagai pembeli dan pemegang hak gadai, adalah petani pemilik lahan luas, pedagang, pegawai/karyawan dan aparat desa. Sepanjang tahun 2008-2009 mereka yang terlibat dalam pembelian tanah dan pemegang hak gadai di lokasi penelitian disajikan pada Gambar 2 di bawah.

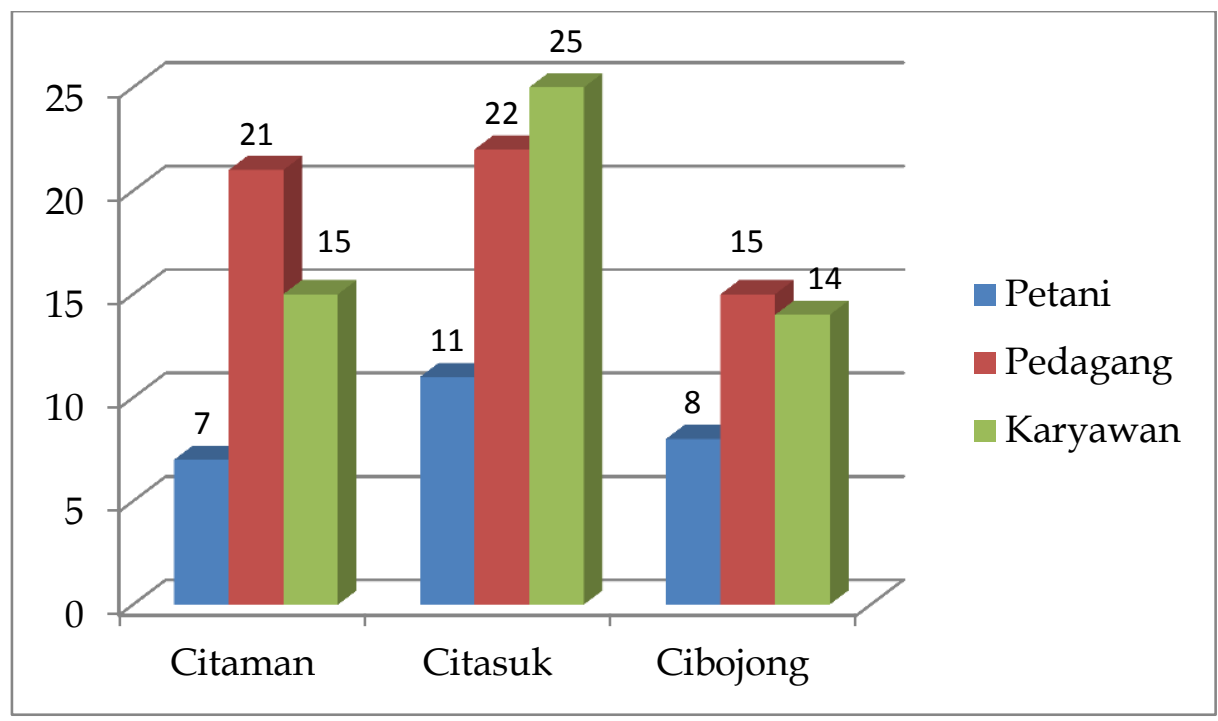

Gambar 2. Grafik Proses Transformasi Penguasaan Tanah Sumber: Diolah dari sumber primer dan buku Cohir

Dari gambar tersebut diketahui, pembeli dan pemegang hak gadai tanah di Desa Citaman dan Cibojong adalah pedagang, sedangkan pembeli dan pemegang hak gadai tanah terbesar di Desa Citasuk berasal dari karyawan/pegawai (negeri dan swasta). Tampilnya pedagang sebagai pembeli dan pemegang hak gadai tanah pada kedua desa, menunjukkan pembangunan pedesaan dan masyarakat sekitar hutan menguntungkan kalangan pedagang dan pemilik lahan luas. Pedagang yang diuntungkan dari pembangunan ekonomi pedesaan adalah pedagang yang menyuplai berbagai jenis kebutuhan pokok warga, membeli dan menampung berbagai komoditas hasil pertanian di tingkat lokal dan antar desa, serta pedagang yang mampu memasarkan komoditasnya ke pusat-pusat perdagangan di Kota Serang, Tangerang, Cilegon dan Jakarta. Tampilnya pedagang, pegawai (negeri dan swasta termasuk aparat desa) dan pemilik lahan luas sebagai pembeli/pemegang hak gadai tanah, menunjukkan bahwa pembangunan pertanian dan kehutanan pedesaan dalam sepuluh tahun di desa sekitar hutan pada satu dekade terakhir berpihak dan menguntungkan orang kuat dan orang kaya di desa dan supra desa. Pelaksanan pembangunan pertanian dan kehutanan, memang meningkatkan 
produktivitas komoditas pertanian dan perkebunan. Tetapi yang menikmati peningkatan produktivitas pertanian itu adalah the strong di desa seperti pedagang, pegawai/karyawan (negeri dan swasta) termasuk aparat desa dan pemilik kebun di atas dua ha. Kondisi ini merupakan implikasi dari politik pembangunan pertanian dan kehutanan bersifat padat modal dan economy of scale. Akibatnya teknologi dan aliran dana yang masuk ke pedesaan, sebagian besar dinikmati oleh elit desa (pemilik lahan luas dan kelompok tertentu) yang dekat dengan birokrat desa atau jalur lain yang memiliki akses terhadap sumber dana itu.

Dari pengamatan dan penggalian informasi juga diketahui bahwa sejalan dengan komoditifikasi sumberdaya, maka pembangunan fisik material lebih menonjol daripada pengembangan sosial dan kemandirian rakyat. Meningkatnya pembangunan jalan disertai tersedianya sarana transportasi pedesaan di wilayah Kecamatan Ciomas dan Padarincang, memudahkan arus masuk keluar barang dan orang ke pusat perdagangan dan pemerintahan di Kota Serang dan sekitarnya. Pembangunan jaringan listrik dan sarana komunikasi, juga menambah lama denyut kehidupan warga pada malam hari dan memudahkan komunikasi serta akses informasi penduduk dengan luar dan supra desa.

Di sisi lain meningkatnya pembangunan infrastruktur, terindikasi kuat berhasil memacu pola hidup konsumtif masyarakat. Peningkatan konsumsi keluarga petani melampaui peningkatan kapasitas produksinya. Lebih besar pasak dari tiang dan semakin tergantungnya kebutuhan komunitas petani kepada pasar. Kondisi ini menurut Soetrisno, (1995) mengindikasikan bahwa pembangunan ekonomi pedesaan telah merangsang rumah tangga petani untuk hidup dalam "budaya kredit". Meluasnya budaya kredit ditandai di mana sebagian ibu rumah tangga lebih senang memasak nasi menggunakan rice cooker, yang dibeli secara kredit, meskipun kayu bakar masih tersedia di sekitarnya. Di tengah tersedianya kayu bakar, memasak nasi dengan rice cooker hanya menambah beban rumah tangga membayar listrik.

Komodifikasi agraria selain memicu tumbuhnya pola hidup hidup konsumtif, juga ternyata memicu meluasnya pemilikan tanah in-absentia di wilayah Kecamatan Ciomas dan Padaricang. Gejala demikian menggambarkan bahwa komodifikasi agraria bukan hanya diikuti dengan beroperasinya moda produksi kapitalis pada komunitas sekitar hutan, tetapi juga mengakibatkan penggusuran dan alienasi petani depeasanitation process), yakni pemiskinan penguasaan aset produksi petani yakni tanah. Area persawahan dan perkebunan di lokasi penelitian, yang sebelumnya dikuasai petani, dewasa ini beralih tangan kepada "petani berdasi" dan orang kota. Bila tak ada upaya strategis dan tindakan politik yang berarti untuk memperbaiki kehidupan petani, penggusuran dan alienasi petani yang berlangsung dewasa ini pada ketiga desa, dapat mengarah pada fenomena sosial yang disebut Hobsbawm, (1985) the death of the peasantry atau deruralization dan deagrarianization processes Bryceson( 2000). Penggusuran dan alienasi petani atau dissolving kehidupan petani merupakan implikasi dari beroperasinya sistem produksi kapitalis di 
wilayah pedesaan. Penggusuran dan alienasi petani disebabkan surplus value dari peningkatan produktivitas pertanian dan komoditas agroforestry terdistribusi secara timpang. Pemilik modal, majikan dan pemilik lahan luas memperoleh surplus value lebih besar dari peningkatan produktivitas pertanian dan pendapatan di luar pertaniaan. Sebaliknya tenaga kerja dan buruh upahan memperoleh surplus value lebih kecil dari yang seharusnya, karena dieksploitasi oleh pemilik modal dan pemilik lahan luas, sebagian di antaranya adalah orang kota.

Meningkatnya penguasaan sumberdaya agraria oleh orang kota dalam aktivitas agroforestry di lokasi penelitian, ternyata disertai semakin dominannya kekuatan produksi non lahan (bahan, alat, modal dan keterampilan) yang berasal dari luar dan untuk mendapatkannya petani dipaksa melakukan hubungan pertukaran ekonomi di pasar. Penguasaan faktor produksi non lahan oleh bukan petani, mendorong semakin terintegrasi dan tergantungnya petani kepada kekuatan supra lokal untuk menopang aktivitas ekonominya. Meningkatnya ketergantungan petani dalam proses produksi kepada pihak luar, bersamaan dengan penguasaan produksi berupa sumberdaya agraria merupakan bentuk nyata penggusuran dan alienasi petani.

Secara sosiologis dampak lebih lanjut dari depeasanisasi adalah memperlemah modal sosial masyarakat desa karena gempuran budaya luar dan supra desa. Interaksi sosial masyarakat desa yang sebelumnya bersifat personal mengalami perubahan menjadi berciri instrumental dan transaksional. Jaringan masyarakat desa yang sebelumnya berorientasi kedalam, homogen dan terbatas menjadi berorientasi keluar, heterogen dan semakin meluas. Sifat-sifat khas dan batas dari setiap varian budaya yang sebelumnya terkait dengan kelompok dan status, etnis dan wilayah geografis, mengalami perubahan makna simboliknya. Fenomena tersebut menunjukkan bahwa dinamika budaya telah menimbulkan persoalan bagi pembentukan identitas budaya. Pembentukan identitas budaya tidak lagi merujuk pada kelompok pendukung, status sosial dan daerah kebudayaan tertentu, tetapi semakin menyebar dan meluas. Dalam istilah Abdullah (1999: 11), dinamika budaya telah mengalami perubahan dari baunded system ke borderles system. Kondisi ini disebabkan rendahnya political will dan political action pemerintah dalam pemberdayaan masyarakat desa, memberikan perlindungan termasuk perlindungan tanah masyarakat pedesaan dari gempuran kekuatan pasar.

\section{SIMPULAN}

Politik agraria berorientasi betting on the strong diakui berdampak positif mendorong pertumbuhan ekonomi dan produktivitas pertanian. Tetapi arah dan orientasi politik tersebut menimbulkan ketimpangan struktur agraria dan pada desa masyarakat sekitar hutan tidak memperbaiki status desa sekitar hutan sebagai kantong kemiskinan. Kondisi ini terkait dengan pendekatan pembangunan kehutanan yang kurang mempertimbangkan manusia sebagai komponen ekosistem hutan dan peranserta masyarakat lokal dalam tata kelola 
sumberdaya hutan. Dalam tata kelola hutan, masyarakat sekitar hutan ditempatkan sebagai sebagai "sumber gangguan, the other, orang pasisian dan perambah hutan".

Penempatan petani di sekitar hutan sebagai the other dan stigmatisasi sebagai orang pasisian, menyebabkan semakin terbatasnya akses dan kesempatan petani untuk mendapat manfaat ekonomi dan upaya peningkatan kesejahteraan dari program pembangunan kehutanan dan pertanian. Kondisi ini terkait dengan rendahnya political will dan political action pemerintah untuk memberdayakan masyarakat pedesaan. Dampak lebih lanjut dari proses tersebut adalah penetrasi kekuatan supralokal (negara dan pasar) yang membonceng masuk pedesaan melalui program pembangunan, bias ke atas dan meninbulkan ketimpangan struktural yang berujung pada pengusuran petani (depeasanitation processes). Fenomena ini menggambarkan bahwa satu dekade pelaksanaan reformasi dan otonomi daerah belum mampu untuk mewujudkan tujuan politik agraria untuk sebesar-besarnya kemakmuran.

\section{DAFTAR PUSTAKA}

Abdullah, Irwan. 1999. "Dari Bounded System ke Bordless Society: Krisis Metode Antropologi Dalam Memahami Masa Kini", Antropologi Indonesia. No. 60 Tahun XXIII.

Agger, Ben. 2003. Teori Sosial Kritis: Kritik, Penerapan dan Implikasinya. Yogyakarta: Kreasi Wacana.

Brinkerhoff, Derick W, and Arthur A. Goldsmith. 1992. "Promoting the Sustainability of Development Institutions: A Framework for Strategy", World Development, Vol. 20.

Bryceson, Deborah; Cristóbal Kay, and Jos Mooij. 2000, Disappearing Peasantries? Rural Labour in Africa, Asia and Latin America, London: Intermediate Technology Publications.

Eric Wolf. 1985. Petani: Suatu Tinjauan Antropologis. Jakarta CV Rajawali.

Ellen, Roy, "Pengetahuan tentang Hutan, Transformasi Hutan: Ketidakpastian Politik, Sejarah Ekologi dan Renegosiasi Terhadap Alam di Seram Tengah," dalam Tania Murray Li (peny.), 2002. Proses Transformasi Daerah Pedalaman di Indonesia. Jakarta: Yayasan Obor Indonesia.

Escobar, Arturo. 1999. "After Nature: Steps to an Antiessentialist Political Ecology" in Current Anthropology Volume 40 Number 1 Februari.

Geertz, Clifford. 1983. Involusi Pertanian. Jakarta: Bhratara.

Hobsbawm, Eric. 1985, Age of Extremes: The Short Twentieth Century 1914-1991, London: Abacus Books, Little, Brown and Co.

Kaplan David dan Albert A Manners. 1999. Teori Budaya. Yogyakarta: Pustaka Pelajar. 
Kenneth Young \& R Tanter. Politik Kelas Menengah Indonesia. Jakarta: LP3ES.

Loekman Soetrisno. 1995. Menuju Masyarakat Partisipatif. Yogyakarta: Kanisius.

Landsberger, Henry. 1984. Pergolakan Petani dan Perubahan Sosial. Jakarta: Rajawali Press

Lubis, Akhyar. 2004. Metode Hermeneutika dan Penerapannya pada Ilmu Sosial, Budaya dan Humaniora. PPS UI, Jakarta.

Lubis, Akhyar. 2004. Paradigma Baru dan Persoalan Metodologi Ilmu SosialHumaniora dan Budaya Pada Era Postmodern. Jakarta: PPS UI.

Matew, Miles dan Michael, Hubermne. 1992. Analisis Data Kualitatif. Jakarta: UI Press.

Nasikun, "Reformasi, Jalan Berliku Menuju Transisi Demokrasi" dalam Mahfud, MD. 1999. Kritik Sosial Dalam Wacana Pembangunan. Yogyakarta: UII Press.

Scott, James. 1989. Moral Ekonomi Petani: Pergolakan dan Subsistensi di Asia Tenggara. Jakarta: LP3ES.

Smith, T Lyn and Zopf, Paul. 1970. Principles of Inductive Rural Sociology, Philadelphia: Davis Company.

Soetrisno, Loekman. 1995. Menuju Masyarakat Partisipatif. Yogyakarta: Kanisius.

Weber, Max. 1968. Economy and Society on Outline of Interpretative Sociology. New York: Bedminster Press. 